\title{
慢性耳鳴に対する柴胡桂枝湯の効果
}

\author{
水田 啓介・伊藤 八次・秋田 茂樹・山田 匡彦 \\ 古田 充哉・早川 和喜・宮田 英雄
}

\section{Effects of Saiko-keishi-to in Patients with Tinnitus}

\author{
Keisuke Mizuta, Yatsuji Ito, Shigeki Akita, Masahiko Yamada, \\ Michiya Furuta, Kazuki Hayakawa and Hideo Miyata \\ (Gifu University School of Medicine)
}

\begin{abstract}
We used Saiko-keishi-to in an attempt to alleviate tinnitus of over 3 months' duration in 13 patients. Saiko-keishi-to was administered orally at 7.5 grams per day, divided into 3 doses, and a subjective evaluation for efficacy was performed 4 weeks thereafter. Of the 13 patients, one was rated as markedly improved, 2 as improved and 2 as slightly improved. In 7 patients who had a favorable response to intravenous lidocaine, 2 were rated as improved and 2 as slightly improved following Saiko-keishi-to administration.

Intravenous lidocaine is effective against tinnitus by blocking the hyperirritable auditory pathway. Saiko-keishi-to acts to suppress the bursts of neurons firing in an epileptic state. We presume that Saiko-keishi-to was more effective in those patients with a good response to lidocaine because of the similar actions of both of these therapies.
\end{abstract}

Key words : tinnitus, Saiko-keishi-to, lidocaine

\section{はじめに}

慢性耳鳴に対しては種々の治療が行われているがその 効果は十分とはいえない，その中でもカルバマゼピンな どの抗けいれん薬は比較的高い有効性が報告されてい る1).しかし抗けいれん薬は副作用の頻度が高く長期間 服用させる場合に注意が必要となる。

柴胡桂枝湯は三叉神経痛やてんかんなど抗けいれん薬 が有効な疾患に効果が報告されたり，抗けいれん薬の使 用量を減少させ得ることが報告されている2) 5). 以上の 点から慢性耳鳴に柴胡桂枝湯が有効である可能性が示唆 される. キシロカイン静脈注射で耳鳴が軽減する症例で は抗けいれん薬が有効なことが多いといら報告1)から， 我々は慢性耳鳴に抗けいれん薬を投与寸る際には, キシ ロカインの静脈注射の耳鳴に対する効果を指標にしてい る.
今回，慢性耳鳴に対する柴胡桂枝湯の効果を検討した。 特にキシロカイン静脈注射試験成績との関連について検 討したので報告する.

\section{対象と方法}

対象は, 当科耳鳴外来を自覚的耳鳴を訴え来科した患 者のらち, 耳鳴発症から 3 カ月以上経過したもので, 柴 胡桂枝湯の投与に同意し 4 週間以上経過観察可能であっ た症例13名(男性 6 名，女性 7 名)である。年齢は男性は 41 歳〜 72歳，平均年齢52.9歳であった。 女性は 44 歳〜 75 歳，平均年齢61.8歳であった(表 1 ).

投与前の検査はまず，耳鳴の評価は耳鳴研究会の判定 基準を用いて大きさ，持続，気になり方を 5 段階評価し た (表 2$)^{6}$. 次いで, 耳鼻咽喉科一般検査に加光, 純音 聴力検査, SISI 検查を行い, 症例によっては自記オー 
表 1 症例一覧

\begin{tabular}{|c|c|c|c|c|c|c|c|c|c|c|c|c|c|c|}
\hline \multirow[t]{2}{*}{ 症 } & \multicolumn{2}{|c|}{ 例 } & \multicolumn{3}{|c|}{ 耳 } & \multicolumn{2}{|l|}{ 鳴 } & \multicolumn{2}{|r|}{ 難 } & \multicolumn{2}{|c|}{ 聴 } & \multirow{2}{*}{$\begin{array}{l}\text { キシロ } \\
\text { カイン } \\
\text { 試 験 }\end{array}$} & \multirow{2}{*}{ CMI } & \multirow{2}{*}{ 証 } \\
\hline & 年歯令 & 性 & 患側 & 罹病期間 & 大きさ & 持続 & $\begin{array}{l}\text { 気にな } \\
\text { り方 }\end{array}$ & 種類 & 左 & 右 & 障害部位 & & & \\
\hline 1 & 63 & 男 & 左 & 3年 & 2 & 4 & 2 & 感音 & 正 & 軽 & 内耳 & 軽快 & II型 & 虚 \\
\hline 2 & 44 & 女 & 左 & 3年 & 3 & 4 & 3 & 感音 & 正 & 軽 & 内耳 & 軽快 & II型 & 間 \\
\hline 3 & 53 & 男 & 両 & 10年 & 2 & 4 & 2 & 感音 & 軽 & 軽 & 内耳 & 無効 & I 型 & 間 \\
\hline 4 & 54 & 女 & 両 & 5年 & 2 & 4 & 1 & 感音 & 中 & 中 & 内耳 & 軽快 & I 型 & 間 \\
\hline 5 & 63 & 男 & 両 & 2年 & 3 & 4 & 3 & 感音 & 軽 & 軽 & 後迷路 & 軽快 & I 型 & 実 \\
\hline 6 & 72 & 男 & 左 & 1.3 年 & 3 & 4 & 4 & 感音 & 高 & 高 & 内耳 & 施行せず & II型 & 間 \\
\hline 7 & 56 & 女 & 左 & 2年 & 2 & 4 & 1 & 混合 & 正 & 中 & 不明 & 施行せず & I 型 & 間 \\
\hline 8 & 70 & 女 & 両 & 30年 & 3 & 4 & 2 & 感音 & 軽 & 軽 & 内耳 & 軽快 & I 型 & 間 \\
\hline 9 & 66 & 女 & 左 & 4 力月 & 2 & 2 & 2 & 感音 & 軽 & 軽 & 内耳 & 施行せず & I 型 & 間 \\
\hline 10 & 75 & 女 & 左 & 5年 & 3 & 4 & 3 & 感音 & 軽 & 中 & 内耳 & 施行せず & 正型 & 間 \\
\hline 11 & 66 & 男 & 両 & 2年 & 2 & 4 & 1 & 感音 & 軽 & 軽 & 後迷路 & 消失 & 施行せず & 間 \\
\hline 12 & 68 & 女 & 左 & 4年 & 3 & 4 & 3 & 感音 & 正 & 中 & 内耳 & 軽快 & 施行せず & 間 \\
\hline 13 & 41 & 男 & 両 & 3年 & 3 & 4 & 3 & - & 正 & 正 & 不明 & 無効 & II型 & 間 \\
\hline
\end{tabular}

表 2 耳鳴評価法6)

1) 耳鳴の大きさ

\begin{tabular}{c|c|c|c|c}
\hline \hline 4 & 3 & 2 & 1 & 0 \\
\hline $\begin{array}{c}\text { とても } \\
\text { 大さい }\end{array}$ & 大きい & 中くらい & 小さい & $\begin{array}{c}\text { 小ても } \\
\text { 小さい }\end{array}$
\end{tabular}

2 ) 耳鳴の持続

\begin{tabular}{|c|c|c|c|c|}
\hline 4 & 3 & 2 & 1 & 0 \\
\hline $\begin{array}{l}\text { いつも鳴 } \\
\text { っている }\end{array}$ & $\begin{array}{l}\text { たまに } \\
\text { とまる }\end{array}$ & $\begin{array}{l}\text { 鳴ったり } \\
\text { とまったり }\end{array}$ & $\begin{array}{l}\text { たまに } \\
\text { 鳴る }\end{array}$ & $\begin{array}{l}\text { 湮とんど } \\
\text { 鳴らない }\end{array}$ \\
\hline
\end{tabular}

3）鵈の気になり方

\begin{tabular}{|c|c|c|c|c|}
\hline 4 & 3 & 2 & 1 & 0 \\
\hline $\begin{array}{l}\text { 気になって } \\
\text { 仕事が手に } \\
\text { つかない }\end{array}$ & $\begin{array}{l}\text { 気になる } \\
\text { が仕事は } \\
\text { できる }\end{array}$ & $\begin{array}{l}\text { 仕事中も } \\
\text { 异ざき } \\
\text { 気になる }\end{array}$ & $\begin{array}{l}\text { 仕事中は } \\
\text { 忘れてい } \\
\text { る }\end{array}$ & $\begin{array}{l}\text { ほとんど } \\
\text { 気になら } \\
\text { ない }\end{array}$ \\
\hline
\end{tabular}

ジオメトリーや ABR などを施行し，可能な範囲で障害 部位診断を行った. CMI も調査した. 証は丁7)のアン ケート形式の質問表による点数評価で判定した.

投薬は柴胡桂枝湯(ツムラ)を $7.5 \mathrm{~g} 1$ 日 3 回, 食間に 4 週間以上継続内服させた。キシロカイン静脈注射試験 を施行し得た 9 例では, 静脈注射試験成績と本薬の効果 との関連を検討した。

耳鳴に対する効果判定は患者の自己評価に基づき, 治 療前の耳鳴を10とした時, 治療により耳鳴がどれくらい
になったかを，治療後の点数（10点法）で評価した． 4 点 以下を著効， $5 \sim 6$ 点を有効， $7 \sim 8$ 点をやや有効， 9 〜10点を無効，11点以上を悪化とし 5 段階に評価した.

\section{成 績}

1 . 柴胡桂枝湯の治療効果

表 3 に全例の自己評価による成績を示した．慢性耳鳴

表 3 キシロカイン静注試験と柴胡桂枝湯の治療成績

\begin{tabular}{c|c|c|c}
\hline & $\begin{array}{c}\text { キシロカイン } \\
\text { 試験成績 }\end{array}$ & $\begin{array}{c}\text { 耳鳴の変化 } \\
\text { (自己評価) }\end{array}$ & 効果判定 \\
\hline 1 & 軽快 & $10 \rightarrow 7$ & やや有効 \\
\hline 2 & 軽快 & $10 \rightarrow 10$ & 無効 \\
\hline 4 & 無効 & $10 \rightarrow 10$ & 無効 \\
\hline 5 & 軽快 & $10 \rightarrow 6$ & 有効 \\
\hline 6 & 軽快 & $10 \rightarrow 10$ & 無効 \\
\hline 7 & 施行せず & $10 \rightarrow 10$ & 無効 \\
\hline 8 & 施行せず & $10 \rightarrow 9$ & 無効 \\
\hline 9 & 軽快 & $10 \rightarrow 10$ & 無効 \\
\hline 10 & 施行せず & $10 \rightarrow 10$ & 無効 \\
\hline 11 & 施行せず & $10 \rightarrow 3$ & 著効 \\
\hline 12 & 消失 & $10 \rightarrow 5$ & 有効 \\
\hline 13 & 軽快 & $10 \rightarrow 8$ & やや有効 \\
\hline 無効 & $10 \rightarrow 10$ & 無効
\end{tabular}



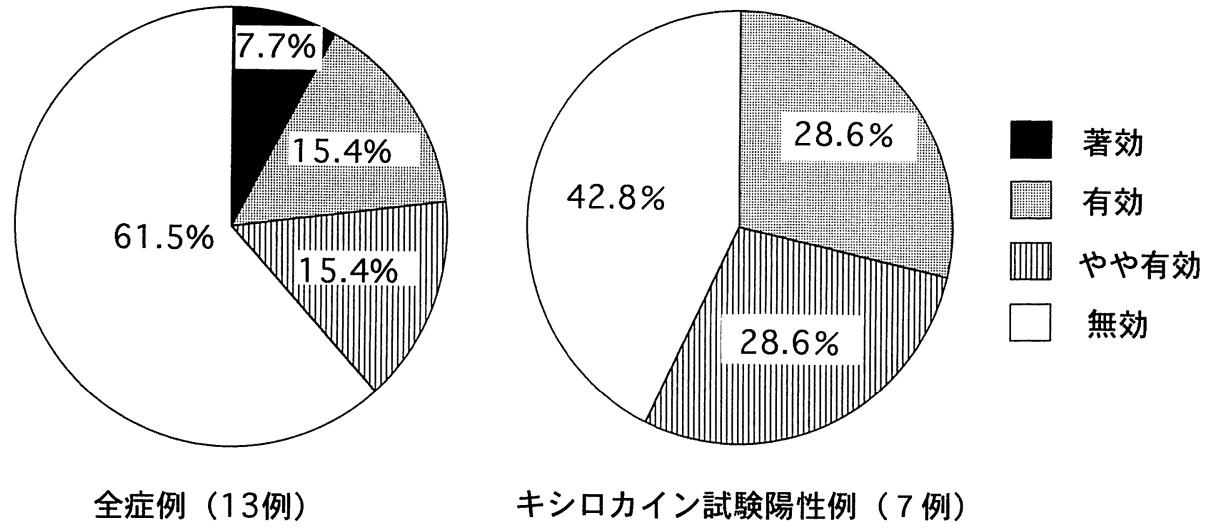

図 1 柴胡桂枝湯の耳鳴に対する自己評価による効果

例13例に対寸る効果は著効 1 例 (7.7\%)，有効 2 例(15.4 $\%$ ，やや有効 2 例 (15.4\%) で，有効以上は $23.1 \%$ ，や や有効以上は $38.5 \%$ であった(図 1 ).

2. キシロカイン静脈注射の成績と柴胡桂枝湯の効果 との関連

キシロカイン静注試験は 9 例に施行できたが，キシロ カイン試験で消失, 軽快した 7 例での柴胡桂枝湯の効果 は有効 2 例 (28.6\%)，やや有効 2 例(28.6\%)で，やや有 効以上は $57.1 \%$ であった（図 1 )。全例に対する有効率上 り高かった。な掞，キシロカイン無効であった 2 例は柴 胡桂枝湯は無効であった.

\section{考 察}

耳鳴に対して，キシロカイン静脈注射が有効な例があ るのは知られている8199. この効果は内耳への作用 ${ }^{81}$, 中 枢麻酔作用 ${ }^{9}$, 膜安定化作用に上る聴覚伝導路の活動電 位減少 ${ }^{10)}$ ，脳幹網様体のブロック1)，血管けいれんの緩 和作用などが考えられている。このキシロカインが有効 な例では抗けいれん薬が効果があると報告されて扔りり， このキシロカイン静注試験結果で抗けいれん薬投与の適 応が考虑されている。

一方，柴胡桂枝湯はやや虚証を対象に寸る漢方薬で, 感冒など急性上気道炎の亜急性期や，腹痛などの消化器 疾患が適応疾患であるが，心身症や精神神経症状への応 用が考えられて拈り，てんかんや三叉神経痛に有効であ るとの報告がある2) 5).

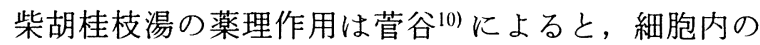
カルシウムの移動や結合蛋白変化を制御することにより,
けいれん波誘発時の神経細胞の異常発火を抑制し, 神経 線維に対しても軽度の麻酔作用を有するとされている。 この作用があるためにてんかんへの有効性が期待されて いる. 耳鳴の発症機序はてんかんや痛みとの類似性が指 摘されているため, 柴胡桂枝湯がある種の耳鳴に効果が あるのではないかと考光た。また，この薬理作用とキシ ロカイン静注の作用の類似性から, キシロカイン静注で 効果のある耳鳴には特に効果的ではないかと考えた。

耳鳴に対する漢方薬投与の報告は釣藤散，牛車腎気丸， 柴朴湯，柴胡桂枝湯の報告があるが，多くはやや有効以 上は $60 \%$ 以上である. 今回の治療成績は $38.5 \%$ でそれは ど高いものでなかったが，対象を慢性耳鳴に限ったこと も効果が低くなった要因と思われる。しかし，キシロカ

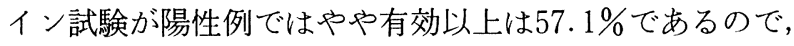
対象をキシロカイン静脈注射が有効である例に限るとあ る程度の効果は期待できると思われた。 また，てんかん や三叉神経痛例に対する使用報告では柴胡桂枝湯に加光， 主要生薬である苟薬を増やすことにより効果を高めたり， カルバマゼピン(テグレトール(®) との併用の工夫で効果 を高めていることから，柴胡桂枝湯単独では効果の少な い例でもキシロカイン試験陽性例ではカルバマゼピンと の併用で効果の上昇を期待できると思われる.

$$
\text { まとめ }
$$

慢性耳鳴例に対して柴胡桂枝湯を投与し効果を検討し た．有効以上は $23.1 \%$ ，やや有効以上は $38.5 \%$ であった。 本剂の薬理作用の特徵から, キシロカイン静脈注射試験 が有効であった例に本剤を使用したところ有効は $28.6 \%$, 
やや有効以上は $57.1 \%$ と有効率が上がった. キシロカイ ン静脈注射試験で効果のある例では試用してもよい薬剤 と思われる.

\section{参考文献}

1) Shea JJ, Emmett JR, Orchik DJ, et al : Medical treatment of tinnitus. Ann Otol $90: 601 \sim 607,1981$.

2）森下孝仁：三叉神経痛に対する柴胡桂枝湯の効果. 痛みと 漢方 1:38 40, 1991.

3) 岡田まゆみ, 吉川秀康, 大野健次: 三叉神経痛に対する柴 胡桂枝湯の使用経験. 痛又と漢方 $6: 61 \sim 64,1996$.

4）鈴木憲一：抗けいれん剮服用者に対する漢方薬の併用例.
漢方診療 $8: 40 \sim 44,1989$.

5 ) 吉田耕治, 草野秀一, 坂元 力, 他 : てんかん合併妊婦に 対する柴胡桂枝湯の使用経験. 漢方訩療 $9 ： 49 \sim 51,1990$.

6) 耳鳴研究会 : 標準耳鳴検査法1984. 1 9 頁, 1984.

7) 丁 宗鐵: 症状別病気別・漢方薬の選び方. 頼られる漢方 治療医ガイド．44～45頁, 講談社, 東京, 1995.

8 ) 安田宏一, 西田之昭, 池田雄祐: 耳鳴飞対する局所麻醉剂 静注の効果. 耳喉 $45 ： 97 \sim 100,1973$.

9 ）卜部信行, 杉原三郎, 山本哲夫, 他: キシロカイン静脈内 投与による耳鳴抑制効果. 耳鼻臨床 $77: 1429 \sim 1436,1984$.

10）菅谷英一 : 柴胡桂枝湯の基礎的研究 一次の時代の医学一 のヒントー. Prog Med 13:1713〜1733, 1993. 